九州大学学術情報リポジトリ

Kyushu University Institutional Repository

\title{
Two new species of Axi idae (Thalassinidea, Crustacea) from the East China Sea
}

Miyake, Sadayoshi

Zoological Laboratory, Department of Agriculture, Kyushu University

Sakai, Katsushi

Zoological Laboratory, Department of Agriculture, Kyushu University

https://doi.org/10.5109/22763

出版情報：九州大学大学院農学研究院紀要. 14 (2)，pp. 303-309，1967-03. Kyushu University バージョン：

権利関係 : 
Journal of the Faculty of Agriculture, Kyushu University, Vol. 14, No. 2

March 30, 1967

\title{
Two new species of Axiidae (Thalassinidea, Crustacea) from the East China Sea ${ }^{1,2)}$
}

\author{
Sadayoshi Miynke and Katsushi SakaI
}

\begin{abstract}
New addition to the Thalassinidae will be reported here from the collection of our laboratory; Axiopsis (Axiopsis) polyacantha sp. nov. and Calocaris (Calastacus) amakusana sp. nov., both of them are found in the East China Sca.

The authors are much indebted to Mr. Hideo Yamashita of the Seikai Regional Fisheries Research Laboratory, Nagasaki for sending us his valuable specimens.
\end{abstract}

\section{Axiopsis (Axiopsis) polyacantha sp. nov.}

Diagnosis. Rostrum triangular with two lateral spines, its tip pointed. Carapace covered with numerous spinules, gastric region flat with five spinulate carinae. First legs subequal, spinose and hairy; chela and carpus jointed to merus obliquely (P1. 4, fig. A).

Description. Holotypic female. Body length $51 \mathrm{~mm}$. Rostrum triangular, and its lateral margin bears two spines. Orbit indistinct, and no hepatic and antennal spines. All over the carapace ornamented with numerous spinules. The five carinae on the gastric region spinulate, its median carina reaching to the cervical groove. There is another row of spinules between the median and submedian carinae (Fig. 1, A-B).

Eyes subglobose, reaching almost to tip of the rostrum, cornea black in alcohol. The antennular peduncle reaches with the penultimate segment beyond the rostrum. The antennal peduncle reaches with the distal segment beyond the antennular peduncle; the first segment bears a distinct spine on the outer-lateral margin, and bears three spinules on distal margin, the stylocerite two-thirds times as long as the second

1) Contributions from the Zoological Laboratory, Faculty of Agriculture, Kyushu University, No. 360.

2) Contributions from the Amakusa Marine Biological Laboratory, Kyushu University, No. 200. 
segment, the scaphocerite of a medium size, reaching slightly beyond tip of the stylocerite, the third segment shows a large spine at the distal part of the lower margin, and the fourth segment bears two spines on the lower margin, the distal one of which more distinct (Fig. 1, C).

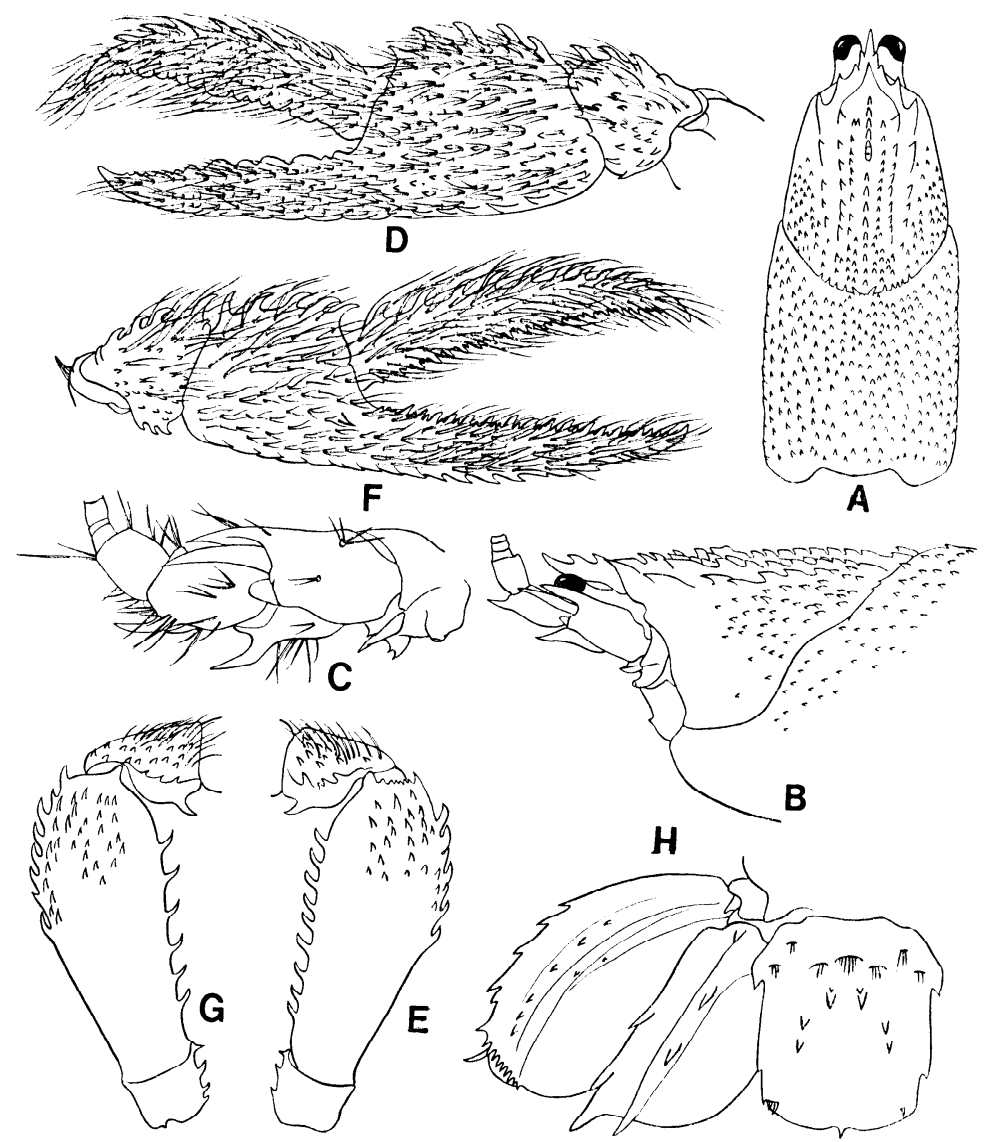

Fig. 1. Axiopsis (Axiopsis) polyacantha sp. nov.

A, Carapace in dorsal view, $\times 3.3$; B, anterior part of carapace in lateral view, $\times 4.8 ; C$, antennal peduncle in outer-lateral view, $\times 9 ; \mathrm{D}$, chela and carpus of larger first leg in outer view, $\times 4.3$; E, merus of larger first leg in outer view, $\times 4.3 ; \mathrm{F}$, chela and carpus of smaller first leg in outer view, $\times 4.3$; G, merus of smaller first leg in outer view, $\times 4.3$; $\mathrm{H}$, telson and uropods in dorsal view, $\times 4.6$.

Carpus of the third maxilliped bears a distal spine on the inner margin. The inner margin of the merus bears four spines growing larger distally in size. The ischium slightly shorter than the merus, 
and bears two spines at the middle. The exopod consists of the proximal segment and the flagellum; the proximal segment fails to reach the distal end of the merus, and the flagellum reaches beyond the distal end of the merus.

The gill-formula as follows:

\begin{tabular}{lccccccccc}
\hline & \multicolumn{4}{c}{ Maxillipeds } & \multicolumn{4}{c}{ Pereiopods } \\
& 1 & 2 & 3 & 1 & 2 & 3 & 4 & 5 \\
\hline Pleurobranchs & - & - & - & - & - & - & - & - \\
Arthrobranchs & - & 1 & 2 & & 2 & 2 & 2 & 2 & - \\
Podobranchs & - & 1 & 1 & 1 & 1 & 1 & - & - \\
Epipods & 1 & 1 & 1 & 1 & 1 & 1 & 1 & - \\
\hline
\end{tabular}

First legs subequal, and its chela and carpus articulated to the merus obliquely. In the larger left leg the cutting edges of the dactylus and the fixed finger show a row of rounded teeth. The upper margin of the dactylus bears seven spines. The palm more than half the length of the dactylus; the upper margin bears five spines, and the lower margin provided with a row of outwards directed spines extending to the fixed finger. The carpus half as long as the palm. The outer surface of the chela and the carpus covered with soft hairs (Fig. 1, D). The merus about as long as the palm and chela combined, bearing a row of spines on the distal half of the upper margin and on the lower margin, the outer surface spinose on the distal part (Fig. $1, E)$. In the smaller right leg the dactylus slender, and its cutting edge, as well as that of the fixed finger, provided with a row of acute teeth. The palm one-third times as long as the dactylus. The other characters very similar to those of the larger left leg (Fig. 1, F-G).

First female's pleopod consists of the proximal segment and the jointed flagellum.

Telson a little longer than broad; the lateral margin bears two small teeth, and bears three spinules at the left postero-lateral angle, the upper surface with four pairs of spines, the posterior three pairs of them much distinct, and the posterior margin bears a median tooth. The exopod of the uropods much longer than the telson; the outer margin armed with a row of spines on the distal half, and the outer rib spinose. The distal lobe of the exopod very small. The endopod has three spines on the outer margin, the distal spine of which forms the distal angle; the midrib bears three spines, the distal spine of them present on the distal margin (Fig. 1, H).

Colour in alcohol. Body brownish.

Holotype. 1 ovig. 우, Zoological laboratory, Kyushu University (ZLKU), No. 9670 , East China Sea $\left(27^{\circ} 16^{\prime} \mathrm{N}, 125^{\circ} 34^{\prime} 5^{\prime \prime} \mathrm{E}\right), 118 \mathrm{~m}$ deep, coll. by 
trawl-net, June 12, 1962, Hideo Yamashita leg.

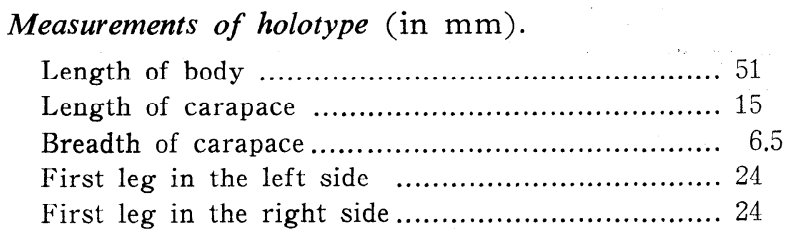

Remarks. This species, of which the carapace is spinulate, is closely allied to Axiopsis (Axiopsis) spinosissima (Rathbun), but it is easely distinguished from the latter by the following characters. Although in A. (Axiopsis) spinosissima the total length of the body reaches $18.5 \mathrm{~mm}$, the rostrum is armed with three lateral spines, and the hepatic and antennal spines are present, the present species is characterized by a body-length of $51 \mathrm{~mm}$, the rostrum has two lateral spines, and the hepatic and antennal spines not exist. According to De Man (1925, p. 99) Rathbun's species has the uropods nearly as long as the telson, but the present species has the uropods longer than the telson. And this species has four pairs of spines on the upper surface of the telson, however Rathbun's species has only four distinct spines.

\section{Calocaris (Calastacus) amakusana sp. nov.}

Diagnosis. Eyes stout and much longer than rostrum. Lateral carina on gastric region provided with two elongate-spines, submedian carina with four spines, and median carina with seven spines, extending to posterior margin of carapace. Exopod of uropods slender, 1.5 times as long as telson (P1. 1, Fig. B).

Description. Holotypic female. Body-length $32 \mathrm{~mm}$. The rostrum shows an elongate-triangular with one or two lateral spines, and at some distance behind the last rostral spine two spines arranged. Orbit indistinct. The lateral carina on the gastric region shows two clongatcspines, the submedian carina four spines, and the median carina provided with seven spines, running throughout the carapace. Posterior margin of the carapace squarely concave (Fig. 2, A-B).

Eyes stout and distinctly longer than the rostrum, its cornea darkbrown in alcohol. Antennular peduncle slightly beyond tip of the eye. Antennal peduncle extends a little beyond tip of the antennular peduncle; the first segment bears the lateral spine, and bears two spinules on the distal margin, the stylocerite less than one-third times as long as the second segment, the scaphocerite a little longer than the stylocerite, and the third segment with three spines on the lower margin (Fig. 2, C).

Carpus of the third maxilliped bears a spine a little behind the distal end of the inner margin. Merus one and one-third times as long as the 
carpus, its inner margin bearing three spines growing larger distally. The ischium shorter than the merus, the inner margin provided with two small spines. The exopod consists of the proximal segment and the flagellum, the proximal segment reaches near to the middle of the merus (Fig. 2, D).

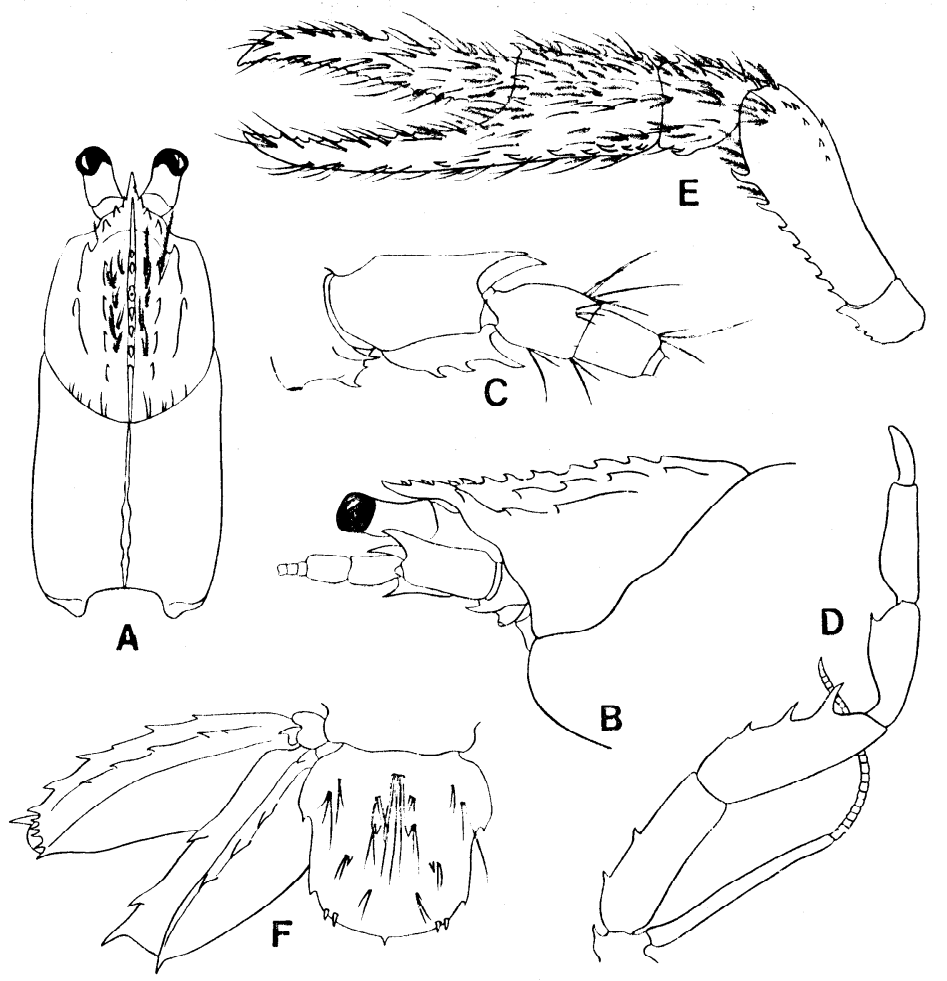

Fig. 2. Calocaris (Calastacus) amakusana sp. nov.

$A$, Carapace in dorsal view, $\times 4.2 ; \mathrm{B}$, anterior part of carpace in lateral view, $\times 6 ; \mathrm{C}$, antennal peduncle in outer-lateral view, $\times 12 ; \mathrm{D}$, third maxilliped in outer view, $\times 8$; E, left first leg in outer view, $\times 5 ; \mathrm{F}$, telson and uropods in dorsal view, $\times 6$.

The gill-formula shown as follows ( $r=$ rudiment):

\begin{tabular}{lccccccccc}
\hline & \multicolumn{3}{c}{ Maxillipeds } & \multicolumn{5}{c}{ Pereiopods } \\
& 1 & 2 & 3 & 1 & 2 & 3 & 4 & 5 \\
\hline Pleurobranchs & - & - & - & - & - & - & - & - \\
Arthrobranchs & - & 1 & 2 & 2 & 2 & 2 & 2 & - \\
Podobranchs & - & $\mathbf{r}$ & - & - & - & - & - & - \\
Epipods & 1 & 1 & 2 & & 2 & 2 & 2 & 1 & - \\
\hline
\end{tabular}


First legs wanting in the right side. In the left side the dactylus slender, and its cutting edge, as well as that of the fixed finger, bears a row of small triangular teeth; the upper margin bears three anteriorly directed spines. The palm about one-half the length of the dactylus and a little longer than broad; the upper margin bears four spines, and the lower margin bears a row of outwards directed spines. The carpus three-fourths times as long as the palm; the upper margin bears two spines, and the lowcr margin bears a pair of spines a little behind the distal angle. The chela and the carpus jointed to the merus obliquely and covered with hairs on the upper surface. The merus a little longer than the palm and carpus combined; its upper margin bears two spines distally, the lower margin shows a row of spines, and the outer surface scattered with some spines on the distal part (Fig. 2, E).

First pleopod in the female provided with the proximal segment and the jointed flagellum.

Telson about as long as broad, bearing two small teeth on the lateral margin and two spinules at the postero-lateral angle; the upper surface bears two pairs of spines, and the posterior margin with a median spine. The exopod of the uropods about 1.5 times as long as the telson, and its outer margin roundly curved with a row of spines; the outer rib spinose. The distal lobe of the exopod very small. The endopod a little shorter than the exopod; the outer margin bears three spines, a distal spine of them stout on the distal margin, and the midrib bears four spines, the distal one of which also lies on the distal margin (Fig. 2, F).

Colour in alcohol. Body yellowish in colour.

Holotype. 1 ㅇ, ZLKU. No. 4580, off Tomioka, Amakusa Island, Kumamoto Prefecture, $20-40 \mathrm{~m}$ deep, coll. by gill-net for spiny lobster fishing, Aug. 22-24, 1956, S. Miyake leg.

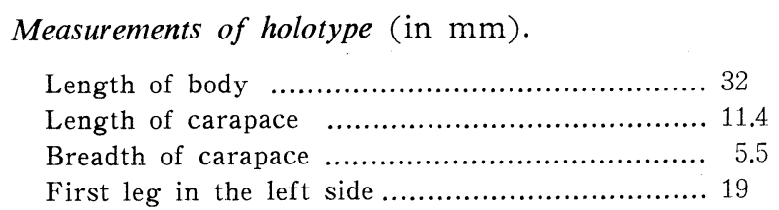

Remarks. It is very difficult to determine the proper genus of the Axiidae, in Dc Man's monograph (1925), this species should be classified in Calocaris (Calastacus) as it has a gastric median carina running throughout the whole length of the carapace, and has the stylocerite and scaphocerite rather large, however the gill-formula of this species differs from Gurney's report (1942, p. 149), in which Calocaris has three podobranchs on the third maxilliped and the first to second pereiopods.

This species is closely related to Axius miyazakiensis Yokoya as the 
eyes are stout, the third maxilliped is very similar in shape, and the uropods, as well as these of Oxyrhynchaxius japonicus Parisi, are projecting, however the present species is distinguished from it as the eyes reach far beyond the tip of the rostrum, spines on the five gastric carinae are differently arranged in shape and number, the median carina runs throughout the carapace, and no longitudinal series of minute spinules is present between the submedian and median carinae. The first leg of the present species seems to be very similar to that of Yokoya's species. However, the present species is missing the larger one, so that it is difficult to compare the two species exactly on this point.

\section{References}

Gurney, R., 1942. “Larvae of Decapod Crustacea.” London.

De Man, J. G., 1925. The Decapoda of the Siboga-Expedition, Part 6. The Axiidae collected by the Siboga-Expedition, Siboga-Expeditie, Mon. 39a5, pp. 98-101, pl. 8, fig. $18, \mathrm{a}-\mathrm{g}$.

Parisi, B., 1917. I Decapodi Giapponesi del Museo di Milano. V. Galatheidea e Reptantia, Atti Soc. Ital. Sci. Nat., vol. 56, pp. 17-23, text-figs. 5-6.

Rathbun, M. J., 1906. The Brachyura and Macrura of the Hawaiian Islands, U. S., Fish Commission, Bulletin for 1903, Part 3, p. 894, text-fig. 50.

Yokoya, Y., 1933. On the distribution of Decapod Crustaceans inhabiting the continental shelf around Japan, chiefly based upon the materials collected by S.S. Soyomaru, during the year 1923-1930. J. Coll. Agr. Tokyo Imp. Univ., vol. 12, no. 1, pp. 51-52, text-fig. 26. 


\section{Explanation of Plate 4}

A. Axiopsis (Axiopsis) polyacantha sp. nov.

B. Calocaris (Calastacus) amakusana sp. nov. 



Two new species of Axiidae from the East China Sea 